\title{
Functional properties of soils formed from biochemical ripening of dredged sediments - subsidence mitigation in delta areas
}

\author{
Bruna R. F. Oliveira ${ }^{1}$ - Martijn P. J. Smit ${ }^{1} \cdot$ Leon A. van Paassen ${ }^{2} \cdot$ Tim C. Grotenhuis $^{1}$ • \\ Huub H. M. Rijnaarts ${ }^{1}$
}

Received: 16 September 2015 / Accepted: 20 September 2016/Published online: 30 September 2016

(C) The Author(s) 2016. This article is published with open access at Springerlink.com

\begin{abstract}
Purpose In delta areas, dense networks of canals have been developed through time and have to be periodically dredged. Lowering the groundwater level in delta areas deepens the aerobic zone, leading to the oxidation of organic matter and possibly to land subsidence. The use of the dredged sediments on land can be a solution to mitigate land subsidence in delta areas.

Materials and methods Five types of dredged sediments with different organic matter content and particle size distribution were dewatered for 7 days and then submitted to biochemical ripening during 141 days on a laboratorial scale with constant temperature and relative humidity. The functional properties analysed were the type and content of organic matter, $\mathrm{pH}$, total C, N, P and S, dry bulk density, water retention capacity, aggregate stability and load-bearing capacity.

Results and discussion After biochemical ripening, there was no significant loss in the mass of organic matter but there was an increase in the fraction of stable organic compounds, observed by an increase in oxygen-bearing compounds and a decrease in hydrocarbons during biochemical ripening. The
\end{abstract}

Responsible editor: Gijs D. Breedveld

Electronic supplementary material The online version of this article (doi:10.1007/s11368-016-1570-7) contains supplementary material, which is available to authorized users.

Bruna R. F. Oliveira

Bruna.Oliveira@wur.nl

1 Environmental Technology, Wageningen University and Research Centre, Bornse Weilanden 9, 6709 WG Wageningen,

The Netherlands

2 Faculty of Civil Engineering and Geosciences, Delft University of Technology, Deft, The Netherlands
$\mathrm{pH}$ was not affected by biochemical ripening, and the total $\mathrm{C}, \mathrm{N}, \mathrm{P}$ and $\mathrm{S}$ concentrations are high and therefore the dredged sediments can improve the quality of the land. Most volume lost during dewatering and biochemical ripening can be attributed to the loss of water. The water retention capacity of the dredged sediments changed with biochemical ripening. The soils formed from biochemical ripening have very stable aggregates, and its load-bearing capacity is enough to sustain cattle and tractors.

Conclusions Most volume lost during dewatering and biochemical ripening can be attributed to the loss of water and not organic matter. Therefore, the studied dredged sediments have potential to mitigate land subsidence in delta areas when spread on land.

Keywords Beneficial use - Biochemical ripening - Dredged sediments $\cdot$ Land subsidence

\section{Introduction}

In many delta areas, dense networks of ditches and canals have been developed through time to regulate the water level, to avoid flooding and to facilitate navigation, transport, agriculture and infra-structure construction. Lowering the groundwater level in these areas deepens the aerobic zone of the soil, leading (especially in peatlands) to the oxidation of organic matter and further land subsidence (Querner et al. 2012).

Some studies report that the high subsidence rates observed in the layer above the groundwater level in low moor peat soils are $15 \%$ ascribed to shrinkage and $85 \%$ to oxidation of organic matter (Schothorst 1977), whereas others relate land subsidence mainly with consolidation (Teatini et al. 2011). Other authors concluded that the contribution of oxidation of organic matter and compaction to land subsidence is variable 
in time (van Asselen 2011). Land subsidence as a result of water discharging is occurring in many low-lying areas and delta areas worldwide (Kolker et al. 2011; Teatini et al. 2011; van Asselen 2011; Wöppelmann et al. 2013), and many attempts are made to attenuate or reverse this process (Querner et al. 2012).

Periodical dredging of ditches and canals is generally performed to maintain their nautical and hydrological functions and improve water quality. Spreading the dredged sediments on land might be a solution to reverse land subsidence by rising the land surface level (Bramley and Rimmer 1988). The practice of spreading dredged sediments on land has been carried out for many years, and all reported studies about this practice refer to the behaviour of contaminants (Vandecasteele et al. 2002; Bedell et al. 2003; Ohimain et al. 2004; Perrodin et al. 2006), without detailed characterization of the properties and behaviour of the sediments.

Dredged sediments are frequently stored in upland deposits and when the clay content is higher than $8 \%$ and/or the organic matter content is higher than $3 \%$, sedimentation, consolidation and ripening occur (Pons and Zonneveld 1965). Sedimentation refers to the settling and rearrangement of the smaller fractions of the particles into multi-particle conglomerates. Sedimentation is a relatively fast process that takes place within hours or days. Coarse or high-density particles have higher sedimentation rates than small- or low-density particles. Sedimentation is followed by consolidation during which the weight of overlying sediment forces out the pore water. The volume occupied by the sediments will only be reduced if the water is able to drain. Therefore, the consolidation rate depends on the permeability of the sediments, the permeability of the boundaries of the deposit and on the height of the sediment layer (Terzaghi et al. 1996). The ripening process is a soil-forming process that converts waterlogged sediments into soils. Ripening of dredged sediments can be subdivided into physical, chemical and biological ripening, even though the three ripening processes proceed simultaneously and interact with each other (Vermeulen et al. 2003).

Previous studies have shown that multiple processes affect the ripening of dredged sediments and subsequent soil formation (Vermeulen 2007; Sheehan et al. 2010; Lafrenz et al. 2013). Some of the functional properties that play an important role in the nature of ripening and affect the properties of the soil are the type of organic matter (Akker et al. 2008; Berglund and Berglund 2011; Schmidt et al. 2011; Urbanek et al. 2011; Guenet et al. 2012; Aich et al. 2013), pH and nutrient content (Ayuke et al. 2011; Knicker 2011; Leue and Lang 2012), water retention capacity (Berglund and Berglund 2011; Bolte et al. 2011; Querner et al. 2012), dry bulk density (van Asselen 2011), aggregate stability (Amézketa 1999; Six et al. 2004; Elmholt et al. 2008; Munkholm 2011; Deviren Saygin et al. 2012) and load-bearing capacity (Gui et al. 2011). The objective of this study is to relate these functional properties of soils formed from different types of dredged sediments after dewatering and biochemical ripening at laboratory scale. In separate studies, the behaviour of sediments was characterised on meso and field scales and the results will be reported elsewhere.

Soil organic matter is associated with soil fertility for plant growth, soil and water quality, soil resistance to erosion and it stores at least three times more carbon than the atmosphere or in living plants (Schmidt et al. 2011; Aich et al. 2013; Kirkels et al. 2014). When dredged sediments are transferred to upland deposits, the oxidation of organic matter begins. Due to oxidation, the type of organic matter will change with time to form stable organic matter compounds. Determination of the type of soil organic matter before and after biochemical ripening will lead to quantification of the stable soil organic matter (Sanei et al. 2005). Furthermore, the total mass of organic matter before and after ripening will lead to insight in the role of organic matter oxidation in land subsidence (Schothorst 1977).

Soil $\mathrm{pH}$ is affected by the soil air, liquid and solid components. The solid components buffer soils to $\mathrm{pH}$ changes caused by natural and anthropic processes. Soil $\mathrm{pH}$ affects a wide range of soil biochemical properties, such as the surface charge of organic matter, clay and mineral particles; the solubility, mobility and toxicity of contaminants; the relative binding of positively charged ions to the cation exchange sites; calcium carbonate equivalents; ion mobility; precipitation and dissolution equilibria and kinetics; oxidation-reduction equilibria; and nutrient availability (Winfield and Lee, 1999; Sumner 2000). Soil pH also affects the decomposition of organic matter by determining the microbial activity and growth (Delaune et al. 1981; Madigan et al. 2010).

Soil organic matter is a source of energy and nutrients for soil biota and plants. The more stable fraction of soil organic matter has a near constant carbon $(\mathrm{C})$, nitrogen $(\mathrm{N})$, phosphorus $(\mathrm{P})$ and sulphur $(\mathrm{S})$ ratio and has higher $\mathrm{N}, \mathrm{P}$ and $\mathrm{S}$ content per unit of $\mathrm{C}$ than less stable organic matter (Kramer et al. 2003; Kirkby et al. 2013). Some authors hypothesised that the availability of N, P and S may limit the stabilization of organic matter (Lal 2008; Knicker 2011; Kirkby et al. 2013). In addition, changes in the structure of the organic matter significantly alter the soil texture and structure, and the nutrient dynamics leads to organic matter with varying $\mathrm{C} / \mathrm{N} / \mathrm{P} / \mathrm{S}$ ratios (Sumner 2000). Dredged sediments are a source of nutrients that can decrease the decomposition of organic matter and increase the fertility of the receiving soil (Fontaine et al. 2011; Leue and Lang 2012).

In some places, dredged sediments can be a significant source of sulphur compounds, and when sulphur compounds that were stable under anaerobic conditions are transferred to an aerobic layer, these can be oxidized and cause acidification which increases the vulnerability of soil to erosion (Bramley and Rimmer 1988; Vermaat et al. 2012). Also, the sulphate 
released can cause soil organic matter degradation with the formation of $\mathrm{CO}_{2}$ (Tichý 1998).

The water content of dredged sediments decreases with time when these are transferred to upland deposits. The removal of water gradually allows oxygen to penetrate through the dredged sediments, changing the conditions from anaerobic to aerobic. The more water removed from the matrix, the more void spaces are available for oxygen penetration which increases organic matter oxidation. The water content affects the properties and behaviour of soils, as the water causes soil particles to swell or shrink, to adhere to each other and to form structural aggregates (Brady and Weil 2008).

Dewatering begins when the dredged sediments are deposited on land or in ripening basins. Soil-water potential can be divided in three components: matric or hydrostatic potential, depending if it refers to the saturated or unsaturated zone, osmotic potential and gravitational potential. All of these components act simultaneously and affect water behaviour in soils (Brady and Weil 2008). In this study, the gravitational potential and osmotic potential are considered constant. Only the matric potential is operational in unsaturated samples and results from adhesive forces and capillarity (Brady and Weil 2008). A matric potential of $-100 \mathrm{hPa}$, or water potential (pF) 2, corresponds to field capacity, i.e. the matric potential at which the plants are regarded to have their optimal water intake and a pF 4.2 corresponds to wilting point after which plants can no longer extract water from the soil and microbial activity is inhibited by $80 \%$ (Koorevaar et al. 1983; Vermeulen 2007).

In this study, the term biochemical ripening refers to the combination of biological and chemical processes that take place after dewatering, when the amount of air-filled pores increases. The major biochemical ripening process is the aerobic mineralization of organic matter (Vermeulen et al. 2007).

Soil aggregate stability is an indicator of soil degradation which can be defined as the resistance of the soil against external mechanical and physicochemical destructive forces, including the effects of rainfall, runoff, tillage, heavy machinery, treading by animals, slaking, swelling and shrinkage (Kemper and Rosenau 1986; Amézketa 1999; Munkholm 2011; Deviren Saygin et al. 2012). A soil aggregate is a naturally formed assemblage of mineral particles and organic matter that cohere to each other more strongly than to other surrounding particles, usually by natural forces and substances derived from root exudates and microbial activity. Furthermore, stable soil aggregates can protect occluded soil organic matter (SOM) against decomposition, leading to a possible long-term stabilisation of soil carbon (Baldock and Skjemstad 2000; Bossuyt et al. 2005; Pulleman et al. 2005; van Lützow et al. 2006; Wei et al. 2014; Chaplot and Cooper 2015).

The undrained shear strength is a mechanical characteristic that, given a certain texture, depends on changing parameters such as degree of humidity, density and the strength of the connection between mineral particles (Hamza and Anderson 2005). Soil compaction increases soil load-bearing capacity and decreases soil physical fertility through decreasing storage and supply of water and nutrients (Hamza and Anderson 2005). Soil compaction refers to the rearrangement of the soil particles, decreasing the void space and increasing the soil bulk density (European Soil Portal 2012). Soil compaction also alters the spatial arrangement, size and shape of the soil aggregates (Comoss et al. 2002). When sediments are dredged, the water content is high and behaves as a liquid since there is no structure. During ripening, the waterlogged sediments gradually develop a structure, increasing the permeability and shear strength (Bramley and Rimmer 1988). The soil undrained shear strength can be used to calculate the soil load-bearing capacity and therefore to determine which forces it can sustain without failure. Therefore, to define what use can be given to the newly formed soil, it is necessary to determine its load-bearing capacity.

Several studies regarding the use of dredged sediments characterised only part of the parameters described above, leading to a risk of non-optimal performance of ripened sediments in its beneficial use (Giulio Bernstein et al. 2002; Torres et al. 2009; Zentar et al. 2009; Malasavage et al. 2012; Perrodin et al. 2012; Dang et al. 2013). The objective of this study is to characterise the functional properties of five types of dredged sediments before and after dewatering and biochemical ripening in order to assess their suitability to mitigate land subsidence in agricultural-delta areas. In addition, the contribution of shrinkage and organic matter oxidation to the overall volume lost by the sediments when transferred from water to upland conditions is determined.

\section{Materials and methods}

\subsection{Collection of samples}

Sampling points S1 to S4 were selected within the Green Heart area, province Zuid-Holland, the Netherlands. According to the World Reference Base for soil resource classification, this area is very heterogeneous and mainly composed by fluvisols and histosols (WRB 2014); http://eusoils. jrc.ec.europa.eu/). Using monitoring data from the water board Hoogheemraadschap van Schieland en de Krimpenerwaard (HHSK), the sampling points S1 to S4 were selected with the objective of having distinct particle size distribution and organic matter content, preferably extremes in clay and/or organic matter content. Approximately, 601 of each sample was dredged from small ditches using a bucket.

Sample S5 was dredged in the Wormer- en Jisperveld nature area in the province Noord-Holland. According to the World 
Reference Base for soil resource classification, the area surrounding S5 is classified as histosols (WRB 2014); http://eusoils.jrc.ec. europa.eu/). Currently, the area is a protected wetland and is mostly used for animal husbandry and various recreational activities (Natuurmonumenten2015). Sample S5 was dredged by the water board Hoogheemraadschap Hollands Noorderkwartier (HHNK) from one of these small ditches using a crane, placed in a $1-\mathrm{m}^{3}$ container and sent to the laboratory.

In the laboratory, all dredged sediment samples were manually wet-sieved and the fraction smaller than $2 \mathrm{~mm}$ was stored in airtight containers under anaerobic conditions (under water) at $4{ }^{\circ} \mathrm{C}$ until used in the experiments. The fractions larger than $2 \mathrm{~mm}$ were discarded since soil classification systems only consider fractions smaller than $2 \mathrm{~mm}$ to be soil (Sumner 2000). The fractions larger than $2 \mathrm{~mm}$ were estimated to be less than $15 \%$ of the total mass by observation.

\subsection{Organic matter content, particle size distribution and fibre content of the dredged sediments}

The organic matter content (Table 1) was calculated following the loss on ignition $\left(4 \mathrm{~h}\right.$ at $550{ }^{\circ} \mathrm{C}$ ) method (ISO/TS 17892$1: 2014)$. To facilitate the interpretation of the results, the samples will be presented from S5 to S1 which is from higher to lower organic matter content.

The fibre content (Table 1) was determined following the standard test method for laboratory determination of the fibre content of peat samples by dry mass ASTM D1997-91 (2008).

For determination of the particle size distribution of the mineral fraction (Table 1), the samples were first air-dried and then the organic matter was removed with $\mathrm{H}_{2} \mathrm{O}_{2}$ and the $\mathrm{CaCO}_{3}$ with $\mathrm{HCl}$. The particle size distribution was determined following the ISO standard ISO/TS 17892-4:2014. Fractions $<2,2-16$ and 16-50 $\mu \mathrm{m}$ were determined by the pipet method, and fraction $50-63 \mu \mathrm{m}$ was determined by wet sieving at the Soil Chemical Biological Soil Laboratory
(CBLB) of Wageningen UR. The fractions 63-150, 150-420 and 420-2000 $\mu \mathrm{m}$ were determined by dry sieving by the Soil Physics Laboratory of Wageningen UR.

\subsection{Experimental procedure}

\subsubsection{Dewatering}

To dewater the dredged sediment samples, suction chambers were used where a suction pressure of $-100 \mathrm{hPa}$ was applied below the sample to achieve the matric potential corresponding to field capacity. To retain the fine particles in the suction chambers, a nylon filter with pore size of $0.45 \mu \mathrm{m}$ was used. It was assumed that equilibrium between the matric potential of the sample and the applied suction is reached when the water outflows from the sample ceases (Klute and Dirksen 1986). This was generally observed within 7 days.

Dewatering was done at $20 \pm 1{ }^{\circ} \mathrm{C}$, and the suction chambers were completely closed to the atmosphere, i.e. evaporation was avoided using a lid on the setup. The water removed from the sample was collected in a tube for quantification by weighing. Periodically, a plug on top of the suction chamber was open to release the pressure due to the decrease of the volume by removed water from the sample.

The internal diameter of the suction chambers was $5 \mathrm{~cm}$, and the amount of sample poured in the suction chambers was calculated for each sample individually with the objective of achieving a final height of $1.5 \mathrm{~cm}$, i.e. after dewatering, all samples had $1.5 \mathrm{~cm}$ in height and $5 \mathrm{~cm}$ in diameter. The volume of sample lost during dewatering was calculated from the initial and final mass of the sample, density of water and dry bulk density of the sample.

After dewatering, some samples were sacrificed in order to determine the water and organic matter content. This was done to determine the homogeneity in water content in samples of the same type of dredged sediments.

Table 1 Organic matter content, fibre content and particle size distribution and classification according to the USDA classification system (USDA 1987) and according to the ISO/TS 17892-4:2014

\begin{tabular}{|c|c|c|c|c|c|c|}
\hline \multicolumn{2}{|l|}{ Sample } & S5 & S4 & S3 & $\mathrm{S} 2$ & $\mathrm{~S} 1$ \\
\hline \multicolumn{2}{|c|}{ Organic matter (\%, gom $\mathrm{g}^{-1}$ dry matter $)$} & 45.6 & 16.1 & 11.8 & 11.8 & 6.0 \\
\hline \multicolumn{2}{|c|}{ Fibres $\left(\%, g_{\text {tibers }} \mathrm{g}^{-1}\right.$ dry matter $)$} & 25.9 & 19.6 & 56.5 & 4.1 & 8.2 \\
\hline \multirow[t]{6}{*}{ Particle size distribution } & $<2 \mathrm{~mm}$ & 47.9 & 10.2 & 9.8 & 25.1 & 13.9 \\
\hline & $2-16 \mathrm{~mm}$ & 17.6 & 3.4 & 3.5 & 16.1 & 4.6 \\
\hline & $16-63 \mathrm{~mm}$ & 2.8 & 5.2 & 5.1 & 21.4 & 10.8 \\
\hline & $63-150 \mathrm{~mm}$ & 9.3 & 20.2 & 17.4 & 33.1 & 58.5 \\
\hline & $150-420 \mathrm{~mm}$ & 15.1 & 58.1 & 62.6 & 4.1 & 11.6 \\
\hline & 420-2000 mm & 7.2 & 3.0 & 1.7 & 0.2 & 0.6 \\
\hline \multicolumn{2}{|l|}{ USDA classification } & Clay & Loamy sand & Loamy sand & Loam & Sandy loam \\
\hline \multicolumn{2}{|l|}{ ISO/TS 17892-4:2014 } & Fine grained & Mixed grained & Mixed grained & Fine grained & Mixed grained \\
\hline
\end{tabular}




\subsubsection{Biochemical ripening}

After dewatering, nine samples of each type of dredged sediments were submitted to biochemical ripening in specifically designed batch bottles (BBs) (Electronic Fig. S1). Each sample was placed in one of these BBs which allowed monitoring of individual variations. The BBs were closed to the atmosphere, and the gas phase was periodically monitored to assure that there was biological activity and that there was no oxygen limitation, i.e. oxygen concentration in the headspace was always above $10 \%(\mathrm{v} / \mathrm{v})$. To avoid condensation and keep the relative humidity constant in the BBs, a saturated solution of potassium nitrate $\left(\mathrm{KNO}_{3}\right)$ with a concentration of $360 \mathrm{gl}^{-1}$ was kept inside the BBs. The $\mathrm{KNO}_{3}$ has neutral $\mathrm{pH}$, absorbs about $0.03 \%$ water in $80 \%$ relative humidity over 50 days and in a closed environment at $20{ }^{\circ} \mathrm{C}$ keeps the relative humidity constant at $94.5 \%$. The BBs were operated for 141 days at $20 \pm 1{ }^{\circ} \mathrm{C}$.

To obtain a better insight on the aerobic degradation of organic matter and $\mathrm{O}_{2}$ transport through the samples during biochemical ripening, a PreSens imaging system was used as a non-invasive method (PreSens 2013). This system combines an imaging technology by a digital camera with fluorescent chemical optical sensor foils to visualize 2D distributions of $\mathrm{O}_{2}$ at a specific surface of heterogeneous samples. The sensor foils were calibrated in the BBs without sample and with and without the saturated salt solution of $\mathrm{KNO}_{3}$, following the multipoint calibration described in the manual (PreSens 2013). From the results of the calibration, the $\mathrm{O}_{2}$ sensor foils did not prove to be suitable for measurement of $\mathrm{O}_{2}$ diffusion rate through the samples under the described experimental conditions.

\subsubsection{Analytical methods}

The geotechnical water content was calculated from the oven dry weight of the samples $\left(24 \mathrm{~h}\right.$ at $\left.105{ }^{\circ} \mathrm{C}\right)$ (ISO/TS 178921:2014).

$\mathrm{O}_{2}$ and $\mathrm{CO}_{2}$ in the $\mathrm{BB}$ headspace were measured with gas chromatography (Shimadzu GC-2010) with a thermal conductivity detector (TCD).

The $\mathrm{pH}$ of the dredged sediments was determined directly by immersing the electrode in the wet sediments since the water content was above $70 \%$ for all samples. The $\mathrm{pH}$ of the biochemically ripened sediments was determined on a 1:1 soil-water suspension using a glass electrode (Soil and Plant Analysis Council Inc. 1999).

The total C, N, P and S were determined at the Chemical Biological Soil Laboratory of Wageningen UR, The Netherlands. The dredged sediment samples were centrifuged to separate the solid fraction from the supernatant. The supernatant was then filtrated and the colloid fraction collected in the filter was added to the solid fraction. One sub-sample of the solid fraction was digested with the DigiPrep (aquaregia method, according to NEN-69610) and analysed with a Thermo (type iCAP) ICP-AES. Another sub-sample of the solid fraction was used to analyse total organic $\mathrm{C}$ and total $\mathrm{N}$ with a Leco $\mathrm{C} / \mathrm{N}$ analyser. The total $\mathrm{P}$ and total $\mathrm{S}$ of the liquid fraction were analysed with a Varian ICP-AES, and the total organic carbon and total nitrogen were analysed with a Skalar Segmented Flow Analyser (SFA).

The type of organic matter was characterised with the RockEval $6 \bowtie$ method. The samples of $20 \mathrm{mg}$ of sediments are heated in pyrolysis and oxidation ovens at a heating rate of $25{ }^{\circ} \mathrm{C} \mathrm{min}^{-1}$ of the Rock-Eval $6 \circledR$ apparatus. The pyrolysis occurs between 100 and $650{ }^{\circ} \mathrm{C}$ under an inert atmosphere of $\mathrm{N}_{2}$. During the pyrolysis, the free hydrocarbons present in the sample and the hydrocarbons released by the thermal cracking of organic matter are detected by the flame ionization detector. Simultaneously, the $\mathrm{CO}$ and $\mathrm{CO}_{2}$ released during thermal cracking of oxygen-bearing organic compounds are measured by infrared detectors. The measurement of $\mathrm{CO}$ is conducted up to $570{ }^{\circ} \mathrm{C}$ to avoid interference from the release of inorganic $\mathrm{CO}$ at higher temperatures. The measurement of $\mathrm{CO}_{2}$ is conducted up to $400{ }^{\circ} \mathrm{C}$ to avoid interference from the release of inorganic $\mathrm{CO}_{2}$ at higher temperatures. Following the pyrolysis stage, the sample is transferred to the oxidation oven and heated from 400 to $850{ }^{\circ} \mathrm{C}$ in air, incinerating all the residual organic carbon. The $\mathrm{CO}$ and $\mathrm{CO}_{2}$ released during combustion of residual organic carbon are measured by online infrared detectors. The hydrogen index $(\mathrm{HI})$ is an indicative value for the amount of hydrocarbons released by thermal cracking of organic matter per gramme of total organic carbon (TOC), and the oxygen index $\left(\mathrm{OI}_{\mathrm{RE} 6}\right)$ is an indicative value for the amount of $\mathrm{CO}_{2}$ and $\mathrm{CO}$ by thermal cracking of oxygen-bearing organic compounds per gramme of TOC (Electronic Supplementary Material, Table S2). Changes in the $\mathrm{HI}$ and $\mathrm{OI}_{\mathrm{RE} 6}$ are analysed to evaluate a transition in the type of organic matter. Rock-Eval $6{ }^{\circledR}$ analyses were performed at Deltares, the Netherlands.

The water retention curve determination was performed by the Soil Physics Laboratory of Wageningen UR, the Netherlands. The water retention curve determination was performed in a climatized room, at $16 \pm 1{ }^{\circ} \mathrm{C}$ and a relative humidity of $60 \pm 5 \%$, using pressure plates, according to the ISO 11274:1998. The non-treated samples were filtered and further dried in a $100-\mathrm{cm}^{3}$ sample ring at height of $2.5 \mathrm{~cm}$ of suction. The water retention curve is presented in terms of $\mathrm{pF}$ vs volumetric moisture ratio $\left(\mathrm{cm}^{3} \mathrm{~cm}^{-3}\right)$. The volumetric moisture ratio, $\theta$, is:

$\theta=\frac{V_{1}}{V_{\mathrm{t}}}$

in which $\mathrm{V}_{1}$ is the volume of liquid and $\mathrm{V}_{t}$ the volume of saturated sample. 
Since the starting $\mathrm{pF}$ for the biochemically ripened samples was $\mathrm{pF} 2$ (previously dewatered to this $\mathrm{pF}$ ), the volumetric moisture ratio was normalized to the volume of the sample at $\mathrm{pF} 2, \theta \mathrm{pF} 2$ normalized:

$\theta_{\mathrm{pF} 2 \text { normalized }}=\frac{V_{1}}{V_{\mathrm{Vt}, \mathrm{pF} 2}}$

This normalization was chosen because ripening is an irreversible process (Vermeulen et al. 2003), and re-wetting the samples would lead to unrealistic results. Hence, to compare the water retention curve of the dredged sediments samples (a) with the biochemically ripened samples (c), also the water retention curve of the dredged sediments samples was referenced to the volume of the sample at $\mathrm{pF} 2$.

The volume of the biochemically ripened samples was calculated from the measured dimensions using a marking gauge. The water retention was determined until $\mathrm{pF} 4.2$ since this corresponds to the conditions when plants can no longer extract water from the soil (Vermeulen 2007).

The dry bulk density was determined after air drying a sample and following the linear measurement method described in the standard ISO 17892-2:2014.

Aggregate stability was determined according to the method described by Kemper and Rosenau for wet aggregate stability determination. The calculated aggregate stability varies from 0 - unstable - to 1-very stable (Kemper and Rosenau 1986). This method measures the breakdown of aggregates upon rapid wetting (slaking) and the subsequent breakdown of aggregates due to the mechanical sieving action. The wet sieving apparatus from Eijkelkamp was used for the mechanical sieving.

The undrained shear strength was determined with the fall cone method of the biochemically ripened samples, following the procedure described in the ISO/TS 17892-6:2004. The measured undrained shear strengths were used to calculate the bearing capacity in order to evaluate whether the soil is accessible for cattle and tractors. The bearing capacity of the soil is calculated according to the method described, e.g. in Terzaghi et al. (1996).

$q=s_{\mathrm{c}} d_{\mathrm{c}} c_{\mathrm{u}} N_{\mathrm{c}}+s_{\mathrm{q}} d_{\mathrm{q}} \gamma D N_{\mathrm{q}}+s_{\gamma} 0.5 \gamma B N_{\gamma}$

in which $\mathrm{q}$ is the bearing capacity in $[\mathrm{kPa}], \mathrm{c}_{\mathrm{u}}$ is the undrained shear strength in $[\mathrm{kPa}], \gamma$ is the bulk unit weight of the soil in $\left[\mathrm{kN} \mathrm{m}^{-3}\right], \mathrm{D}$ is the depth at which the load is applied below surface level in [m], B is the width of the load surface in [m] assuming an infinitely long strip footing, $\mathrm{N}_{\mathrm{c}}, \mathrm{N}_{\mathrm{q}}$ and $\mathrm{N}_{\gamma}$ are so-called bearing capacity factors, which are related the friction angle of the soil, $\mathrm{s}_{\mathrm{c}}, \mathrm{s}_{\mathrm{q}}$ and $\mathrm{s}_{\gamma}$ are shape factors which are used to correct for the shape of the surface on which the load is applied and $d_{c}$ and $d_{q}$ are depth factors which need to be taken into account when the load is applied below surface level. Considering that the load of cattle or tractors is applied at surface level and only for a short period of time at the same location, $\mathrm{D}=0 \mathrm{~m}, \mathrm{~N}_{\gamma}=0, \mathrm{~N}_{\mathrm{q}}=1$ and $\mathrm{N}_{\mathrm{c}}=5.14$ (Barnes 2000), the equation above can be simplified to:

$q=\left(1+\frac{N_{\mathrm{q}}}{N_{\mathrm{c}}}\right) c_{\mathrm{u}} N_{\mathrm{c}}=6.14 c_{\mathrm{u}}$

In this empirical approach, the soil is presumed to be infinitely stiff and homogeneous in both horizontal and vertical directions, which are considered to be valid presumptions when the load is applied in the open field. In case a tractor or cow is standing close to a ditch, the bearing capacity may be significantly lower and that scenario was not considered in this study.

The load applied by cattle on the soil was calculated considering an average weight of $600 \mathrm{~kg}$ and considering that the weight is evenly distributed by the four paws with a surface area of $0.01 \mathrm{~m}^{2}$ each. For tractors, it was considered an average weight of $2900 \mathrm{~kg}$ per front wheel and an average weight of $6000 \mathrm{~kg}$ per rear wheel. The values on Table 2 correspond to cattle and tractors operating at the Wormer- en Jisperveld nature area and may vary from place to place.

\section{Results}

The mass of organic matter content determined following the loss on ignition method did not change significantly for any of the five samples during the 7 days of dewatering and during the 141 days of biochemical ripening (Fig. 1). Even though, there was oxygen $\left(\mathrm{O}_{2}\right)$ consumption and carbon dioxide $\left(\mathrm{CO}_{2}\right)$ production (Fig. 2) evidencing that there was microbial activity in the BBs.

The results of $\mathrm{O}_{2}$ consumption and $\mathrm{CO}_{2}$ production have significant error bars which might be justified not only by the natural heterogeneity between biological systems but also by the possible leakage of some of the BBs, since no differences were observed in the organic matter content between replicates. The results in Fig. 2 reflect the total cumulative $\mathrm{CO}_{2}$ production and $\mathrm{O}_{2}$ consumption during 141 days of biochemical ripening. Considering that the samples had $5 \mathrm{~cm}$ in diameter, that biochemical ripening took 141 days and that the rate of $\mathrm{CO}_{2}$ production was constant during biochemical ripening, the average $\mathrm{CO}_{2}$ released from the samples ranged from

Table 2 Estimation of load applied on the soil by cattle and tractors

\begin{tabular}{lllll}
\hline & Mass $(\mathrm{kg})$ & $\begin{array}{l}\text { Surface } \\
\text { area }\left(\mathrm{m}^{2}\right)\end{array}$ & $\begin{array}{l}\text { Number of } \\
\text { paws or wheels }\end{array}$ & $\begin{array}{l}\text { Load [kPa per } \\
\text { (paw or wheel)] }\end{array}$ \\
\hline Cattle & 600 & 0.01 & 4 & 147 \\
Tractor front & 2900 & 0.12 & 2 & 118 \\
Tractor rear & 6000 & 0.24 & 2 & 123 \\
\hline
\end{tabular}


Fig. 1 Dry matter distribution $(a)$ before dewatering, $(b)$ after dewatering and $(c)$ after biochemical ripening

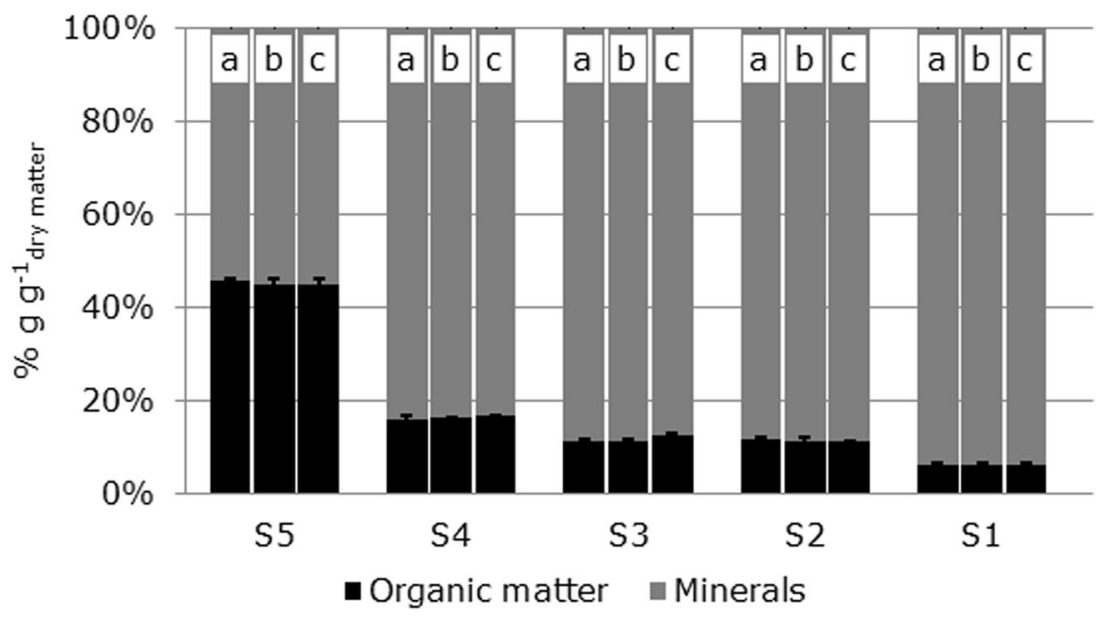

$6.8 \mathrm{~g}_{\mathrm{C}} \mathrm{m}^{-2}$ year $^{-1}$ for S3 (lowest) to $10.8 \mathrm{~g}_{\mathrm{C}} \mathrm{m}^{-2}$ year $^{-1}$ for S1 (highest). Assuming that the samples are not oxygen limited, these rates can be corrected for the $1.5-\mathrm{cm}$ height of the samples, and therefore the average $\mathrm{CO}_{2}$ released ranged from

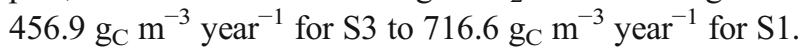

Regarding the type of organic matter, biochemical ripening resulted in a decrease in the $\mathrm{HI}$ and an increase in $\mathrm{OI}_{\mathrm{RE} 6}$ for all the samples, i.e. a decrease in hydrocarbons and an increase in oxygen-bearing compounds (Fig. 3). The percentage of decrease in $\mathrm{HI}$ and percentage of increase in $\mathrm{OI}_{\mathrm{RE} 6}$ seem to be dependent of the composition of each sample and are not proportional. Sample S5 had $27 \%$ increase (highest) in the $\mathrm{OI}_{\text {RE6 }}$ while sample S3 had $3 \%$ increase (lowest) in the $\mathrm{OI}_{\text {RE6 }}$. The decrease in HI was highest for S4 with $13 \%$ and lowest for $\mathrm{S} 3$ with $6 \%$. The smallest increase in $\mathrm{OI}_{\mathrm{RE} 6}$ and smallest decrease in HI were observed for sample S3 which has the highest fibre content (Table 1).

The $\mathrm{pH}$ (Table 3) of the samples was stable during biochemical ripening. The $\mathrm{pH}$ of sample $\mathrm{S} 5$, from North Holland, was lower than the samples from South Holland.

The dry bulk density increases with decreasing organic matter content (Table 3), except for S2 which might be caused by the high clay content (Table 1).

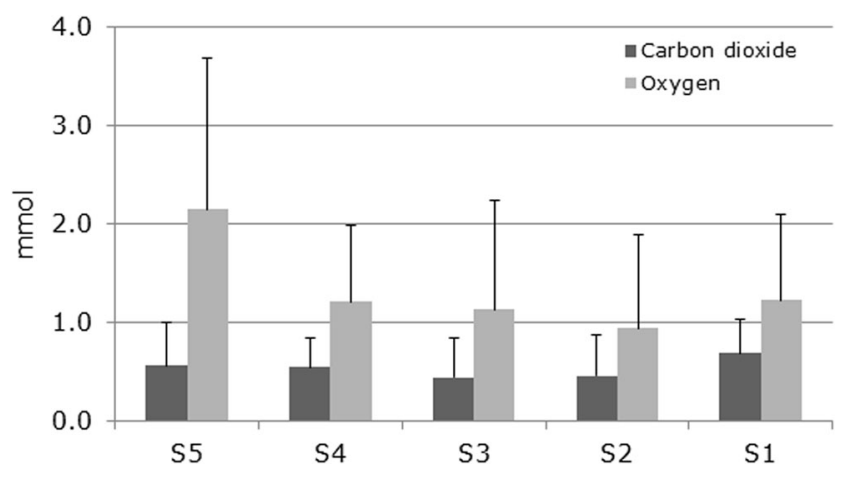

Fig. 2 Average total $\mathrm{CO}_{2}$ produced and $\mathrm{O}_{2}$ consumed (mmol) during the 141 of biochemical ripening. Error bars represent standard deviation of nine replicates
Regarding the total C, N, P and S (Table 4), the observed variations might not be significant due to the heterogeneity of the samples.

The water balance for the dewatering process (Electronic Supplementary Material, Table S1) is closed for 93 to $98 \%$, and therefore losses of water are not significant. Dewatering resulted in the removal of 72 to $52 \%$ of the total water content of the dredged sediments. The sample with highest water dewatered was S1 which is the sample with lowest organic matter content.

From Fig. 4, most water was lost during the dewatering step, but during biochemical ripening also, a significant amount of water was lost. Part of the water during biochemical ripening might be incorporated in the organic compounds or transferred to the $\mathrm{KNO}_{3}$ salt solution.

The water retention curves of the dredged sediments are very similar (Fig. 5). Sample S5 has the strongest water retention capacity, while S1 has the weakest water retention capacity. The results suggest that the higher the organic matter content, the strongest the water retention capacity. S5 has a strong shrinkage behaviour, resulting in a normalized (Eq. (2)) volumetric moisture ratio higher than 1 , due to the very high organic matter and clay content. Samples S2 and S3 have similar

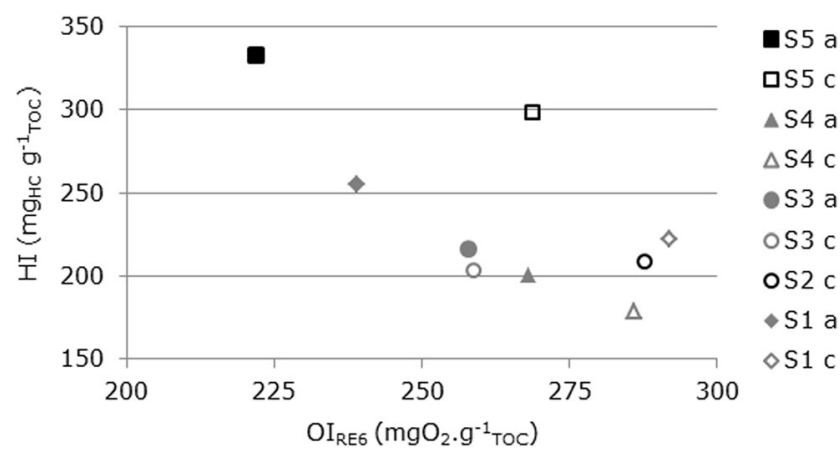

Fig. 3 Hydrogen index $\left(\mathrm{mg}_{\mathrm{HC}} \mathrm{g}^{-1}\right.$ TOC $)$ and oxygen index $\left(\mathrm{mg}_{\mathrm{O} 2} \mathrm{~g}^{-1}\right.$ TOC $)$ of the dredged sediments $(a)$ before dewatering and $(c)$ after biochemical ripening. Hydrogen and oxygen indexes of S2. S2 (a) gave a faulty measurement 
Table $3 \mathrm{pH}$, dry bulk density, aggregate stability index, undrained shear strength and calculated bearing capacity, before dewatering and after biochemical ripening

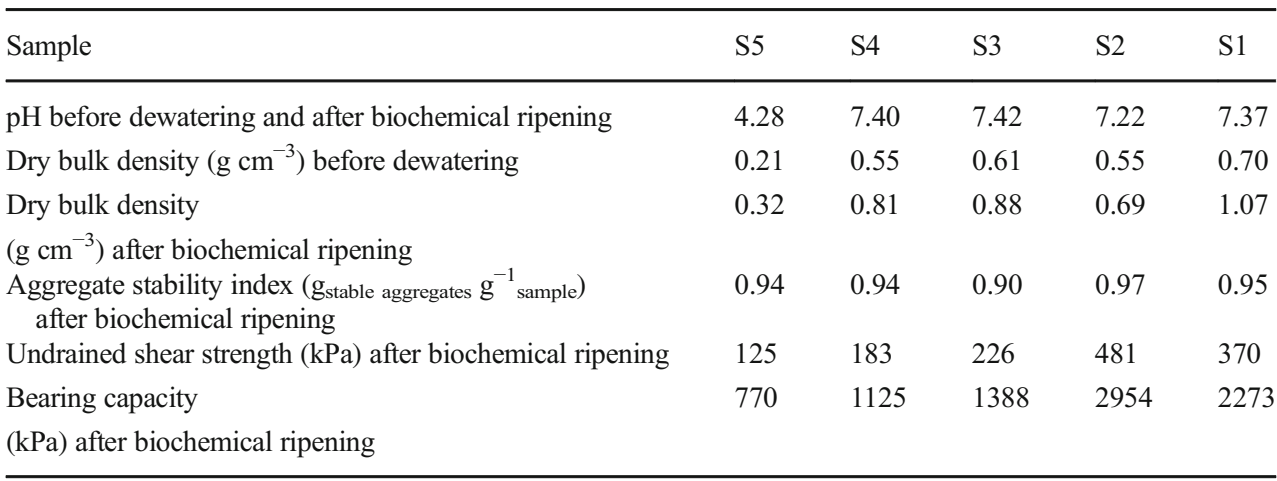

organic matter content, and the difference in behaviour might be caused by highest clay content of $\mathrm{S} 2$ in relation to $\mathrm{S} 3$.

Dewatering and biochemical ripening resulted in an increase of the water retention capacity for samples S5 and S4 and in a decrease for samples S2, S1 and S3 (Fig. 5). At pF 2, biochemical ripening resulted in $43 \%$ increase in the water retention capacity for $\mathrm{S} 5$ and $31 \%$ decrease for $\mathrm{S} 1$. At $\mathrm{pF} 4.2$, biochemical ripening resulted in $53 \%$ decrease in the water retention capacity for S5 and $29 \%$ increase for S1. The change in the composition of the organic matter might explain the variations in the water retention capacity of the soil samples in relation to the dredged sediments (Fig. 5). The higher the water retention capacity, the less air-filling pores which results in less oxygen diffusion and consequently less organic matter oxidation. The aggregate stability indexes obtained (Table 3) suggest that all five samples are very stable to water erosion. The undrained shear strength of the samples after biochemical ripening is presented in Table 3. The lowest undrained shear strength was observed for sample S5 which has the highest organic matter content, while the highest undrained shear strength was observed for sample S2 which has the lowest fibre content (Table 1). The calculated bearing capacity of the samples indicates that the studied dredged sediments can sustain tractors and cattle (according to the calculation in Table 2).

\section{Discussion}

The organic matter content of the samples did not vary significantly after 141 days of biochemical ripening. This result is opposite to earlier findings in which land subsidence of low moor peats in the Netherlands was monitored for 6 years in terms of surface elevation, bulk density, moisture and organic matter content and was $85 \%$ attributed to organic matter degradation and $15 \%$ to shrinkage (Schothorst 1977).

The $\mathrm{CO}_{2}$ released from the samples during biochemical ripening, corrected to the $1.5-\mathrm{cm}$ height of the samples, was $456.9 \mathrm{~g}_{\mathrm{C} \mathrm{m}} \mathrm{m}^{-3}$ year $^{-1}$ for S3 and $716.6 \mathrm{~g}_{\mathrm{C} \mathrm{m}} \mathrm{m}^{-3}$ year $^{-1}$ for S1. Therefore, the results suggest that the samples studied, without the presence of vegetation, are a source of $\mathrm{CO}_{2}$ to the atmosphere.

Field studies performed in the Netherlands, with an average annual precipitation of $800 \mathrm{~mm}$ and an average annual temperature of $9.8^{\circ} \mathrm{C}$, in which the gas fluxes from histosols to the atmosphere were monitored using eddy covariance systems and closed flux chambers report varying fluxes:

- $\quad 330 \mathrm{~g}_{\mathrm{C}} \mathrm{m}^{-2}$ year ${ }^{-1}$ from an abandoned agricultural field converted into a wetland nature reserve (Hendriks et al. 2007)
Table 4 Total carbon (TC), total nitrogen (TN), total phosphorus (TP) and total sulphur (TS) content, before dewatering and after biochemical ripening

\begin{tabular}{llllll}
\hline & $\begin{array}{l}\text { TC } \\
\left(\mathrm{g} \mathrm{kg}^{-1} \text { dry matter }\right)\end{array}$ & TN & TP & TS & C/N/P/S (molar ratio) \\
& 238.60 & 14.66 & 1.21 & 23.48 & $511: 27: 1: 19$ \\
\hline S5, before dewatering & 232.00 & 17.70 & 1.21 & 20.13 & $497: 33: 1: 16$ \\
S5, after biochemical ripening & 88.82 & 6.44 & 1.05 & 10.56 & $218: 14: 1: 10$ \\
S4, before dewatering & 89.10 & 7.20 & 1.25 & 10.93 & $184: 12: 1: 8$ \\
S4, after biochemical ripening & 75.60 & 6.04 & 0.65 & 9.48 & $300: 21: 1: 14$ \\
S3, after biochemical ripening & 67.34 & 4.92 & 1.50 & 6.58 & $116: 7: 1: 4$ \\
S2, before dewatering & 67.80 & 5.60 & 1.63 & 5.51 & $108: 8: 1: 3$ \\
S2, after biochemical ripening & 44.49 & 2.30 & 0.46 & 7.57 & $248: 11: 1: 16$ \\
S1, before dewatering & 48.40 & 2.76 & 0.55 & 7.86 & $229: 11: 1: 14$ \\
S1, after biochemical ripening & & & & & \\
\hline
\end{tabular}




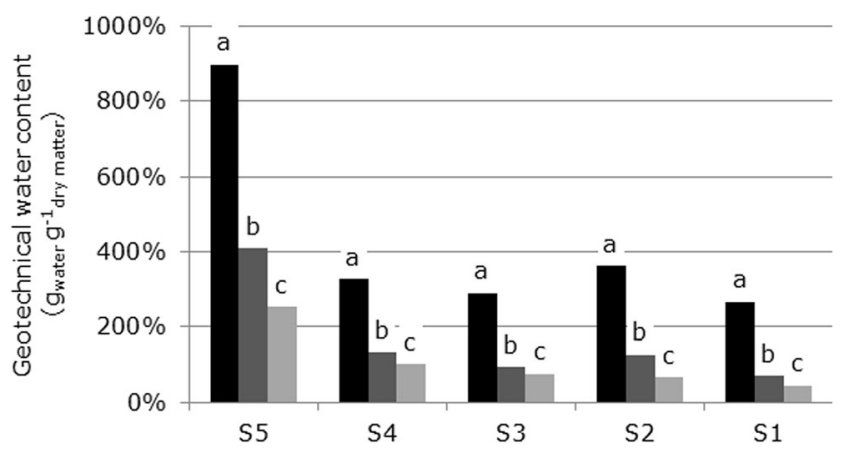

Fig. 4 Geotechnical water content $(a)$ before dewatering, $(b)$ after dewatering and $(c)$ after biochemical ripening

- $130 \mathrm{~g}_{\mathrm{C}} \mathrm{m}^{-2}$ year $^{-1}$ from a peat pasture used for intensive dairy farming (Langeveld et al. 1997)

- $220 \mathrm{~g}_{\mathrm{C}} \mathrm{m}^{-2}$ year $^{-1}$ from grasslands (Jacobs et al. 2007)

- $113.18 \mathrm{~g}_{\mathrm{C}} \mathrm{m}^{-2}$ year $^{-1}$ from an intensively managed grassland (Schrier-Uijl et al. 2014)

- $\quad-409.09 \mathrm{~g}_{\mathrm{C}} \mathrm{m}^{-2}$ year $^{-1}$ (minus signal means uptake) from a re-wetted former agricultural peatland (Schrier-Uijl et al. 2014)

In general, organic soils are often sources of $\mathrm{CO}_{2}$ (Langeveld et al. 1997; Hendriks et al. 2007; Jacobs et al. 2007; Schrier-Uijl et al. 2014) while mineral soils are often a sink of $\mathrm{CO}_{2}$ (Gilmanov et al. 2007; Jacobs et al. 2007). Since the groundwater level in the field varies significantly throughout the year and that the field cover also affects significant the gas and liquid fluxes, it is not easy to compare the results of our experiments with previously reported results since the samples used had a constant height of $1.5 \mathrm{~cm}$ and no vegetation was present. However, it seems that the potential of $\mathrm{CO}_{2}$ release from the studied samples is low compared with field studies.
The Rock-Eval $6 \circledR$ method allows to follow the evolution of the humification process in sediments and soils with time. Our results confirm that there was a change in the type of organic matter since all the treated samples (soil) have lower $\mathrm{HI}$ and higher $\mathrm{OI}_{\mathrm{RE} 6}$ than the correspondent dredged sediments. This means that the treatment resulted in a decrease in free hydrocarbons and an increase in oxygen-bearing organic compounds for all the samples, i.e. the treatment resulted in more stable organic matter. The formation of recalcitrant SOM compounds increases the stability of the organic matter (Six et al. 2002). The decrease in $\mathrm{HI}$ and increase in $\mathrm{OI}_{\mathrm{RE} 6}$ indicate an increase in the humification of the organic matter (Lafargue et al. 1998; Disnar et al. 2003).

More consumption of $\mathrm{O}_{2}$ than production of $\mathrm{CO}_{2}$ indicates the incorporation of oxygen in the organic matter, i.e. the increase in oxygen rich compounds. For instance, sample S5 has the highest $\left[\mathrm{CO}_{2}\right] /\left[\mathrm{O}_{2}\right]$ ratio and also the highest increase in oxygen rich compounds. The activity of communities of microorganisms is also influenced by the $\mathrm{pH}$ (Berg and Laskowski 2005; Rousk et al. 2010; van Roon 2012), and, since S5 is acidic while the other samples are close to neutral, the active microorganisms can differ which also explains the difference in $\left[\mathrm{CO}_{2}\right] /\left[\mathrm{O}_{2}\right]$ ratios.

Considering the $\mathrm{CO}_{2}$ production, the $\mathrm{O}_{2}$ consumption and the Rock-Eval $6 \circledR$ results, it can be concluded that the loss on ignition method might not the best method to detect changes in organic matter under such experimental conditions.

The decrease in water content during biochemical ripening together with the insignificant loss in organic matter content during biochemical ripening indicates that in 141 days of biochemical ripening, most shrinkage was caused by water loss. Sample S1 had the highest loss in total weight during dewatering and biochemical ripening, due to water removal, and is the sample with the highest increase in dry bulk density.
Fig. 5 Water retention curve of the dredged sediments $(a)$ before dewatering and (c) after biochemical ripening

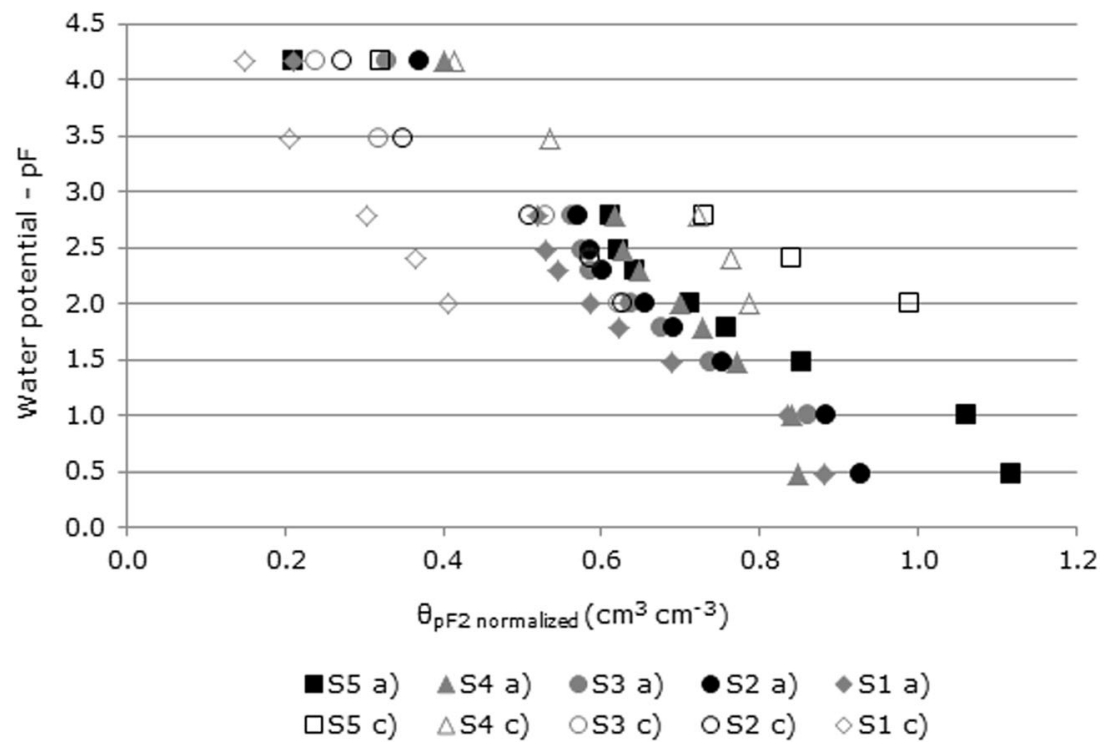


Sample S5 had the lowest loss in total weight during dewatering and biochemical ripening and was the sample with lowest increase in dry bulk density. Therefore, the higher the water removal, the higher the compaction of the sample which was also observed by (Teatini et al. 2011).

The water retention capacity of any material is related with the porosity and the nature of the bonding between water and soil. Coarse-grained materials have water binding mainly by capillary forces, while fine-grained soils have water binding by adhesive and osmotic forces. As a consequence, finegrained soils need higher water potentials to release water than coarse-grained materials. At any given water potential, organic soils usually retain more water than fine-grained soils (Sumner 2000). Our results show that sample S1, with $6 \%$ (dry weight) organic matter and $14 \%$ (of the mineral fraction) clay content, is the sample that retains less water. Sample S5 has $46 \%$ (dry weight) organic matter and $48 \%$ (of the mineral fraction) clay content and is the sample that retains more water until $\mathrm{pF}$ 2.75. For higher water potentials, sample S4, with $16 \%$ organic matter and $10 \%$ clay content, is the sample that retains more water. This might be due to the strong shrinkage behaviour observed for sample S5 (laboratory observation). In general, the results confirm that the higher organic matter content results in more water retention capacity.

Some studies highlight the importance of clay content on the decomposition of organic matter. The clay can physically protect soil organic matter from decomposition when the soil matrix is characterised by a large amount of small pores that create a barrier to decomposing microorganisms. Furthermore, the clay can also chemically protect organic matter from decomposition since the clay particles are active soil components in the production of organo-mineral complexes and the microorganisms are less efficient in decomposing the organic matter protected in these complexes (Krull et al. 2003; van Lützow et al. 2006; Wei et al. 2014). From the particle size distribution and the average total $\mathrm{CO}_{2}$ released and $\mathrm{O}_{2}$ consumed, there is no direct relation between the clay content of the samples and the organic matter decomposition. The $\mathrm{pH}$ was not affected by dewatering and biochemical ripening.

The organic matter decomposition depends also on the availability of nitrogen, phosphorus and sulphur. There is evidence for a constant stoichiometric ratio of $\mathrm{C} / \mathrm{N} / \mathrm{P} / \mathrm{S}$ for the stable portion of the soil organic material across a wide range of global soils. Such a ratio should provide a reliable basis with which to determine the fraction of stable organic matter in soils (Kirkby et al. 2011). In addition, sediments in ditches and canals can accumulate nutrients leached from the adjacent agricultural sites and therefore the agriculture land can benefit from the recycling of these nutrients. Sample S5, S4, S3 and S1 are very rich in carbon and can therefore be representative carbon sinks if the decomposition of organic matter is minimized. Other authors studying Dutch dredged sediments found TC varying from 118 to $53 \mathrm{~g} \mathrm{~kg}^{-1}$ dry matter, $\mathrm{TN}$ varying from 6.9 to
$5.0 \mathrm{~g} \mathrm{~kg}^{-1}$ dry matter, TP varying from 2.5 to $0.9 \mathrm{~g} \mathrm{~kg}^{-1}$ dry matter and TS varying from 18 to $8 \mathrm{~g} \mathrm{~kg}^{-1}$ dry matter

The dredged sediments have a water content ranging from $898 \%$ for S5 to $268 \%$ for S1 (Fig. 4) and, as a consequence, it is not possible to determine the stability and undrained shear strength. Since during dewatering and biochemical ripening of the dredged sediments the excess of water is removed, a structure is developed and the aggregate stability and undrained shear strength can be determined for the newly formed soil.

One indicator of soil degradation is the aggregate stability which can be defined as the resistance of the soil against the external destructive effects of water and wind (Deviren Saygin et al. 2012). The results obtained indicate that the soils formed from biochemical ripening dredged sediments are very stable to water erosion and, as a consequence, the organic matter occluded within the aggregates is protected against biochemical degradation. However, from the observation of the samples in the laboratory during the wet sieving with the dispersant solution, most material was retained in the sieves as if the cohesive forces of the aggregates could not be broken down by the dispersant solution. No literature was found addressing this topic, and therefore these results should be interpreted carefully.

The load-bearing capacity of the biochemically ripened dredged sediments varies between $770 \mathrm{kPa}$ for S5 and $2954 \mathrm{kPa}$ for S1, which is enough to sustain cattle and tractors, meaning that the soil can be used for husbandry (crops and/or animals).

\section{Conclusions}

The studied dredged sediments have the potential to mitigate land subsidence in delta areas when spread on land since:

- The mass of organic matter did not change after dewatering and biochemical ripening.

- Most volume lost during dewatering and biochemical ripening can be attributed to water loss and pore water reduction and not to organic matter loss.

- Biochemical ripening resulted in an increase in oxygenbearing compounds and decrease in hydrocarbons which indicates an increase in the fraction of stable organic compounds.

- The water retention capacity is higher for samples with higher organic matter which is a valuable condition to decrease the oxygen diffusion through the matrix.

- The total C, N, P and S concentrations are high and therefore the dredged sediments can be considered as fertilizer when added to a soil.

- The aggregates formed during biochemical ripening are very stable to water erosion and can protect organic matter against oxidation. 
- The load-bearing capacity after biochemical ripening is enough to sustain cattle and tractors, meaning that the soil can be used for husbandry (crops and/or animals).

\begin{abstract}
Acknowledgments This research is supported by the Dutch Technology Foundation STW, which is part of the Netherlands Organisation for Scientific Research (NWO) and which is partly funded by the Ministry of Economic Affairs, via the perspective program BioGeoCivil (grant 11344). We would like to express gratitude to Guido Verweij from Hoogheemraadschap van Schieland en de Krimpenerwaard (HHSK) and Karsten Hopman from Hoogheemraadschap Hollands Noorderkwartier (HHNK) for the support with sampling; to Gerben Bakker Soil Physics Laboratory Wageningen University and Research Centre for all the input about laboratorial methods about soil sciences; and to Vinnie de Wilde from the sub-department of Environmental Technology Wageningen University and Research Centre for all the support designing the experimental setup.
\end{abstract}

Open Access This article is distributed under the terms of the Creative Commons Attribution 4.0 International License (http:// creativecommons.org/licenses/by/4.0/), which permits unrestricted use, distribution, and reproduction in any medium, provided you give appropriate credit to the original author(s) and the source, provide a link to the Creative Commons license, and indicate if changes were made.

\section{References}

Aich S, McVoy CW, Dreschel TW, Santamaria F (2013) Estimating soil subsidence and carbon loss in the Everglades Agricultural Area, Florida using geospatial techniques. Agric Ecosyst Environ 171: 124-133

Akker JJHvd, Kuikman PJ, Vries Fd, Hoving I, Pleijter M, Hendriks RFA, Wolleswinkel RJ, Simões RTL, KwakernaakS C (2008) Emission of $\mathrm{CO} 2$ from agricultural peat soils in the Netherlands and ways to limit this emission. Proceedings of the 13th International Peat Congress After Wise Use-The Future of Peatlands, Vol. 1 Oral Presentations, Tullamore, Ireland, 8-13 June 2008. Jyväskylä, Finland: International Peat Society, Proceedings of the 13th International Peat Congress, Tullamore, Ireland, 2008-06-08/2008-06-13

Amézketa E (1999) Soil aggregate stability: a review. J Sustain Agric 14: $83-151$

Ayuke FO, Brussaard L, Vanlauwe B, Six J, Lelei DK, Kibunja CN, Pulleman MM (2011) Soil fertility management: impacts on soil macrofauna, soil aggregation and soil organic matter allocation. Appl Soil Ecol 48:53-62

Baldock JA, Skjemstad JO (2000) Role of the soil matrix and minerals in protecting natural organic materials against biological attack. Org Geochem 31:697-710

Barnes GE (2000) Soil mechanics - principles and practice. PALGRAVE

Bedell J-P, Briant A, Delolme C, Perrodin Y (2003) Evaluation of the phytotoxicity of contaminated sediments deposited "on soil". I. Impact of water draining from the deposit on the germination of neighbouring plants. Chemosphere 50:393-402

Berg B, Laskowski R (2005) Decomposers: soil microorganisms and animals, advances in ecological research. Academic Press, Salt Lake City, pp 73-100

Berglund Ö, Berglund K (2011) Influence of water table level and soil properties on emissions of greenhouse gases from cultivated peat soil. Soil Biol and Biochemist 43:923-931
Bolte K, Hartmann P, Fleige H, Horn R (2011) Determination of critical soil water content and matric potential for wind erosion. J Soils Sediments 11:209-220

Bossuyt H, Six J, Hendrix PF (2005) Protection of soil carbon by microaggregates within earthworm casts. Soil Biol Biochem 37: 251-258

Brady NC, Weil RR (2008) The nature and properties of soils, Fourteenth edn. Pearson/Prentice Hall, Upper Saddle River

Bramley RGV, Rimmer DL (1988) Dredged materials - problems associated with their use on land. J Soil Sci 39:469-482

Chaplot V, Cooper M (2015) Soil aggregate stability to predict organic carbon outputs from soils. Geoderma 243-244:205-213

Comoss EJ, Kelly DA, Leslie HZ (2002) Innovative erosion control involving the beneficial use of dredge material, indigenous vegetation and landscaping along the Lake Erie Shoreline. Ecol Eng 19:203-210

Dang TA, Kamali-Bernard S, Prince WA (2013) Design of new blended cement based on marine dredged sediment. Constr Build Mater 41: 602-611

Delaune RD, Reddy CN, Patrick WH Jr (1981) Organic matter decomposition in soil as influenced by $\mathrm{pH}$ and redox conditions. Soil Biol Biochem 13:533-534

Deviren Saygin S, Cornelis WM, Erpul G, Gabriels D (2012) Comparison of different aggregate stability approaches for loamy sand soils. Appl Soil Ecol 54:1-6

Disnar JR, Guillet B, Keravis D, Di-Giovanni C, Sebag D (2003) Soil organic matter (SOM) characterization by Rock-Eval pyrolysis: scope and limitations. Org Geochem 34:327-343

Elmholt S, Schjønning P, Munkholm LJ, Debosz K (2008) Soil management effects on aggregate stability and biological binding. Geoderma 144:455-467

European Soil Portal (2012) Glossary of soil terms

Fontaine S, Henault C, Aamor A, Bdioui N, Bloor JMG, Maire V, Mary B, Revaillot S, Maron PA (2011) Fungi mediate long term sequestration of carbon and nitrogen in soil through their priming effect. Soil Biol Biochem 43:86-96

Gilmanov TG, Soussana JF, Aires L, Allard V, Ammann C, Balzarolo M, Barcza Z, Bernhofer C, Campbell CL, Cernusca A, Cescatti A, Clifton-Brown J, Dirks BOM, Dore S, Eugster W, Fuhrer J, Gimeno C, Gruenwald T, Haszpra L, Hensen A, Ibrom A, Jacobs AFG, Jones MB, Lanigan G, Laurila T, Lohila A, Manca G, Marcolla B, Nagy Z, Pilegaard K, Pinter K, Pio C, Raschi A, Rogiers N, Sanz MJ, Stefani P, Sutton M, Tuba Z, Valentini R, Williams ML, Wohlfahrt G (2007) Partitioning European grassland net ecosystem $\mathrm{CO} 2$ exchange into gross primary productivity and ecosystem respiration using light response function analysis. Agric Ecosyst Environ 121:93-120

Giulio Bernstein A, Bonsembiante E, Brusatin G, Calzolari G, Colombo P, Dall'Igna R, Hreglich S, Scarinci G (2002) Inertization of hazardous dredging spoils. Waste Manag 22:865

Guenet B, Juarez S, Bardoux G, Abbadie L, Chenu C (2012) Evidence that stable $\mathrm{C}$ is as vulnerable to priming effect as is more labile $\mathrm{C}$ in soil. Soil Biol Biochem 52:43

Gui Y, Cao J, Song ZG, Zhang Q (2011) Evaluation of undrained shear strength of converting dredged material to agricultural soil. Appl Mech Mater Eng Appl 147:191-196

Hamza MA, Anderson WK (2005) Soil compaction in cropping systems: a review of the nature, causes and possible solutions. Soil Till Res 82:121

Hendriks DMD, van Huissteden J, Dolman AJ, van der Molen MK (2007) The full greenhouse gas balance of an abandoned peat meadow. Biogeosciences 4:411

Jacobs CMJ, Jacobs AFG, Bosveld FC, Hendriks DMD, Hensen A, Kroon PS, Moors EJ, Nol L, Schrier-Uijl A, Veenendaal EM (2007) Variability of annual CO2 exchange from Dutch grasslands. Biogeosciences 4:803

Kemper WD, Rosenau RC (1986) Aggregate stability and size distribution. In: Klute A (ed) Methods of soil analysis. Part 1—physical and 
mineralogical methods, Second edn. American Society of Agronomy, Inc. and Soil science Society of America, Inc, Madison, pp. $425-442$

Kirkby CA, Kirkegaard JA, Richardson AE, Wade LJ, Blanchard C, Batten G (2011) Stable soil organic matter: a comparison of C:N: P:S ratios in Australian and other world soils. Geoderma 163:197

Kirkby CA, Richardson AE, Wade LJ, Batten GD, Blanchard C, Kirkegaard JA (2013) Carbon-nutrient stoichiometry to increase soil carbon sequestration. Soil Biol Biochem 60:77

Kirkels FMSA, Cammeraat LH, Kuhn NJ (2014) The fate of soil organic carbon upon erosion, transport and deposition in agricultural landscapes - a review of different concepts. Geomorphology 226:94

Klute A, Dirksen C (1986) Water retention: laboratory methods. In: Klute A (ed) Methods of soil analysis. Part 1—physical and mineralogical. Methods, 2nd edn. American Society of Agronomy, Inc. and Soil science Society of America, Inc, Madison, pp. 635-686

Knicker H (2011) Soil organic N-an under-rated player for C sequestration in soils? Soil Biol Biochem 43:1118-1129

Kolker AS, Allison MA, Hameed S (2011) An evaluation of subsidence rates and sea-level variability in the northern Gulf of Mexico. Geophys Res Lett 38:L21404

Koorevaar P, Dirksen C, Menelik G (1983) Elements of soil physics. Developments in soil science 13. Elsevier, Amsterdam

Kramer MG, Sollins P, Sletten RS, Swart PK (2003) N isotope fractionation and measures of organic matter alteration during decomposition. Ecology 84:2021-2025

Krull ES, Baldock JA, Skjemstad JO (2003) Importance of mechanisms and processes of the stabilisation of soil organic matter for modelling carbon turnover. Funct Plant Biol 30:207-222

Lafargue E, Marquis F, Pillot D (1998) Rock-Eval 6 applications in hydrocarbon exploration, production, and soil contamination studies. Oil Gas Sci Technol 53:421

Lafrenz MD, Bean RA, Uthman D (2013) Soil ripening following dam removal. Phys Geogr 34:124

Lal R (2008) Promise and limitations of soils to minimize climate change. J Soil Water Conserv 63:113A-118A

Langeveld CA, Segers R, Dirks BOM, van den Pol-van Dasselaar A, Velthof GL, Hensen A (1997) Emissions of CO2, CH4 and N2O from pasture on drained peat soils in the Netherlands. Eur J Agron 7:35

Leue M, Lang F (2012) Recycling soil nutrients by using channel deposits as fertilizers? Nutr Cycl Agro Eco Sys 93:75-88

Madigan MT, Martinko JM, Stahl DA, Clark DP (2010) Brock biology of microorganisms. 13th Edition

Malasavage N, Jagupilla S, Grubb D, Wazne M, Coon W (2012) Geotechnical performance of dredged material - steel slag fines blends: laboratory and field evaluation. J Geotech Geoenviron 138:981

Munkholm LJ (2011) Soil friability: a review of the concept, assessment and effects of soil properties and management. Geoderma 167-168: 236-246

Natuurmonumenten (2015) Natuurmonumenten-Wormer- en Jisperveld. Over dit natuurgebied

Ohimain EI, Andriesse W, van Mensvoort MEF (2004) Environmental impacts of abandoned dredged soils and sediments. J Soils Sediments 4:59

Perrodin Y, Babut M, Bedell J-P, Bray M, Clement B, Delolme C, Devaux A, Durrieu C, Garric J, Montuelle B (2006) Assessment of ecotoxicological risks related to depositing dredged materials from canals in northern France on soil. Environ Int 32:804

Perrodin Y, Donguy G, Bazin C, Volatier L, Durrieu C, Bony S, Devaux A, Abdelghafour M, Moretto R (2012) Ecotoxicological risk assessment linked to infilling quarries with treated dredged seaport sediments. Sci Total Environ 431:375

Pons LJ, Zonneveld IS (1965) Soil ripening and soil classification: initial soil formation of alluvial deposits with a classification of the resulting soils. Publication 13, International Institute for Land Reclamation and Improvement

PreSens (2013) Oxygen sensor foil for imaging SF-RPSu-instructions manual. Document name: IM_SF-RPSu4ddv2. PreSens-Precision Sensing GmbH, Germany

Pulleman MM, Six J, Van Breemen N, Jongmans AG (2005) Soil organic matter distribution and microaggregate characteristics as affected by agricultural management and earthworm activity. Eur J Soil Sci 56: 453-467

Querner EP, Jansen PC, van den Akker JJH, Kwakernaak C (2012) Analysing water level strategies to reduce soil subsidence in Dutch peat meadows. J Hydrol 446-447:59-69

Rousk J, Brookes PC, Bååth E (2010) Investigating the mechanisms for the opposing $\mathrm{pH}$ relationships of fungal and bacterial growth in soil. Soil Biol Biochem 42:926-934

Sanei H, Stasiuk LD, Goodarzi F (2005) Petrological changes occurring in organic matter from recent lacustrine sediments during thermal alteration by Rock-Eval pyrolysis. Org Geochem 36:1190-1203

Schmidt MWI, Torn MS, Abiven S, Dittmar T, Guggenberger G, Janssens IA, Kleber M, Kogel-Knabner I, Lehmann J, Manning DAC, Nannipieri P, Rasse DP, Weiner S, Trumbore SE (2011) Persistence of soil organic matter as an ecosystem property. Nature 478:49

Schothorst CJ (1977) Subsidence of low moor peat soils in the western Netherlands. Geoderma 17:265-291

Schrier-Uijl AP, Kroon PS, Hendriks DMD, Hensen A, Van Huissteden J, Berendse F, Veenendaal EM (2014) Agricultural peatlands: towards a greenhouse gas sink - a synthesis of a Dutch landscape study. Biogeosciences 11:4559-4576

Sheehan C, Harrington J, Murphy JD (2010) A technical assessment of topsoil production from dredged material. Resour Conserv Recy 54: $1377-1385$

Six J, Conant RT, Paul EA, Paustian K (2002) Stabilization mechanisms of soil organic matter: implications for C-saturation of soils. Plant Soil 241:155-176

Six J, Bossuyt H, Degryze S, Denef K (2004) A history of research on the link between (micro) aggregates, soil biota, and soil organic matter dynamics. Soil Till Res 79:7-31

Soil and Plant Analysis Council Inc (1999) Soil analysis handbook of reference methods. CRC Press LLC, Boca Raton

Sumner ME (2000) Handbook of soil science. CRC Press, Boca Raton

Teatini P, Tosi L, Strozzi T (2011) Quantitative evidence that compaction of Holocene sediments drives the present land subsidence of the Po Delta, Italy. J Geophys Res 116:B08407

Terzaghi K, Peck RB, Mesri G (1996) Soil mechanics in engineering practice. Wiley-Interscience, New York

Tichý R (1998) Bioleaching of metals from soils or sediments using the microbial sulfur cycle. Wageningen Agricultural University, Wageningen

Torres P, Manjate RS, Fernandes HR, Olhero SM, Ferreira JMF (2009) Incorporation of river silt in ceramic tiles and bricks. Ind Ceram 29:5

Urbanek E, Smucker AJM, Horn R (2011) Total and fresh organic carbon distribution in aggregate size classes and single aggregate regions using natural ${ }^{13} \mathrm{C} /{ }^{12} \mathrm{C}$ tracer. Geoderma $164: 164-171$

USDA (1987) Soil mechanics level 1, module 3-USDA textural classification study guide, national employee development staff, soil conservation service. United States Department of Agriculture, Washington DC

van Asselen S (2011) The contribution of peat compaction to total basin subsidence: implications for the provision of accommodation space in organic-rich deltas. Basin Res 23:239-255

van Lützow M, Kögel-Knabner I, Ekschmitt K, Matzner E, Guggenberger G, Marschner B, Flessa H (2006) Stabilization of organic matter in temperate soils: mechanisms and their relevance under different soil conditions - a review. Eur J Soil Sci 57:426-445 
van Roon MR (2012) Wetlands in the Netherlands and New Zealand: optimising biodiversity and carbon sequestration during urbanisation. J Environ Manag 101:143-150

Vandecasteele B, De Vos B, Tack FMG (2002) Heavy metal contents in surface soils along the Upper Scheldt river (Belgium) affected by historical upland disposal of dredged materials. Sci Total Environ 290:1-14

Vermaat J, Harmsen J, Hellmann F, Harm vG, Jeroen dK, Kosten S, Smolders F, Verhoeven J (2012) Zwaveldynamiek in het WestNederlandse laagveengebied, Sectie Aarde en Economie, Faculteit Aard- en Levenswetenschappen. Vrije Universiteit Amsterdam, Amsterdam

Vermeulen J (2007) Ripening of PAH and TPH polluted sedimentsdetermination and quantification of bioremediation parameters. Wageningen University and Research Centre, Wageningen

Vermeulen J, Grotenhuis T, Joziasse J, Rulkens W (2003) Ripening of clayey dredged sediments during temporary upland disposal a bioremediation technique. J Soils Sediments 3:49-59

Vermeulen J, van Gool MPM, Dorleijn AS, Joziasse J, Bruning H, Rulkens WH, Grotenhuis JTC (2007) Biochemical ripening of dredged sediments. Part 1. Kinetics of biological organic matter mineralization and chemical sulfur oxidation. Environ Toxicol Chem 26:2530

Wei H, Guenet B, Vicca S, Nunan N, Asard H, AbdElgawad H, Shen W, Janssens IA (2014) High clay content accelerates the decomposition of fresh organic matter in artificial soils. Soil Biol Biochem 77:100

Winfield LE, Lee CR (1999) Dredged material characterization tests for beneficial use suitability. U.S. Army Engineer Research and Development Center, Vicksburg

Wöppelmann G, Le Cozannet G, de Michele M, Raucoules D, Cazenave A, Garcin M, Hanson S, Marcos M, Santamaría-Gómez A (2013) Is land subsidence increasing the exposure to sea level rise in Alexandria, Egypt? Geophys Res Lett 40:2953

WRB IWG (2014) World reference base for soil resources 2014. International soil classification system for naming soils and creating legends for soil maps. World soil resources reports no. 106. FAO, Rome

Zentar R, Abriak NE, Dubois V, Miraoui M (2009) Beneficial use of dredged sediments in public works. Environ Technol 30:841 